\author{
Mykola Orlenko \\ ๑ https://orcid.org/0000-0002-4154-2856 \\ Honorary President of the "Ukrrestavratsiya" Corporation \\ n_orlenko2012@ukr.net
}

\author{
Yulia Ivashko \\ ๑ https://orcid.org/0000-0003-4525-9182 \\ Kyiv National University of Construction and Architecture \\ yulia-ivashko@ukr.net
}

\title{
THE CONCEPT OF ART AND WORKS OF ART IN THE THEORY OF ART AND IN THE RESTORATION INDUSTRY
}

\begin{abstract}
At all times, art has quickly responded to the evident and concealed socio-political processes in the society. Starting from the first decades of the twentieth century, the semantic meaning of the terms "art" and "work of art" gradually has changed; art does not always refer to the category of beauty, and therefore the criteria for the selection of artefacts to works of art also has changed. The transformation of the phenomenon into art occurs gradually: first it arises spontaneously, then specific genres and professionals appear, then it becomes a social phenomenon and holds a particular niche in the cultural life of society. So, art should be a means of educating society, which develops according to the laws of aesthetics and composition, and in this case, the elemental phenomenon becomes an artistic phenomenon.

The restoration industry is quite conservative; it adheres to the criteria for defining a work of art and the basics of preserving and reproducing a work of art that developed during the 20th and 21 st centuries, in which restoration includes painting, murals, sculpture, carving, iconostasis, furniture, fabrics.
\end{abstract}

Keywords: art, work of art, restoration industry, criteria for determination 


\section{Introduction}

\section{The concept of "art" and "a work of art" at different times and in the theories of art}

If you trace when exactly art had become a separate specific aesthetic category and aesthetic phenomenon, ${ }^{1}$ it can be proved that this had happened during the times of ancient civilizations - Egyptian, Mesopotamian, Persian, Indian, Greek, Roman, Maghreb, Arabic, because since that time, we can talk about the presence of a particular original artistic style and, therefore, about the formation of art in its traditional sense, as noted in the publications of M. Dyomin, ${ }^{2}$ A. Marder, ${ }^{3}$ O. Ivashko ${ }^{4}$ and other authors.

It is significant that, along with traditional forms of art, mathematics geometry and arithmetic - played a relevant part in ancient civilizations and the most prominent contribution to the development of mathematics as science was made by the scholars of ancient Greece.

The role of mathematics was so significant that mathematical relationships (especially the so-called "golden section" ratio) were reflected in the proportions of outstanding architectural objects and the construction of musical works (rhythm). So, to some extent, mathematics was not considered as art, but it had a direct impact on the traditional arts. In ancient Greece, architecture, sculpture, painting, arts and crafts, literature, theatre, music were considered art and honoured by 9 music patrons of the arts - Calliope (epic poetry), Euterpe (lyrical poetry and music), Melpomene (tragedy), Talia (comedy), Erato (love poetry), Polyhymnia (pantomime and hymns), Terpsichore (dance), Clio (history), Urania (astronomy).

In ancient Greece, the seven liberal arts stand out, and it was during antiquity that the list of sciences (academic disciplines) was distinguished, which later became known as the liberal arts, the totality of which was the preparatory stage for the study of philosophy. In the 5th century, Martianus Minneus Felix Capella made an allegorical review of the seven liberal arts in the treatise "On the Marriage of Philology and Mercury". At that time the term "art" was not considered as "artistry," (such understanding of art was formed only in the mo-

Art - a short dictionary on aesthetics. http://esthetics.ru - iskusstvo. July 29, 2013.

M. M. Dyomin, M. I. Orlenko, The systematic approach to monuments and restoration activities. Urban planning and territorial planning: Scientific and technical collection. Osietrin, M.M. (Ed.) Kyiv, KNUCA. Issue 65, 2017, pp. 21-32.

3 A. P. Marder, Yu. M. Yevreinov, O. A. Plamenytska, et al. Architecture. Abridged dictionary. Under the general editorship of A. P. Marder. Kyiv, 1995.

4 O. Iwaszko, Społeczna Przyroda Nowych Artystycznych kierunków w Miejskim Srodowisku. Przestrzeń / Urbanistyka / Architektura, 2/2018, pp. 167-176. 
dern age), but primarily as a practical science. Meanwhile, the seven liberal arts were levels of education: the art of oratory (grammar and rhetoric), the mental process (dialectics or logic) and numbers (arithmetic, geometry, astronomy, the theory of music). Liberal arts were divided into two stages - trivium (three arts) and quadrivium (four arts). Quadrivium arose earlier, in antiquity, and arithmetic was considered the eldest of its sciences; trivium emerged in the early Middle Ages, and there the totality of liberal arts was considered a preparatory stage for obtaining a philosophical understanding of the world. In medieval universities, seven liberal arts were studied at the junior art department, after which students received the academic title of Master of Arts and could enroll in the senior faculty - theological, medical or legal. In the Middle Ages, the arts of trivium were grammar, logic and rhetoric; quadrivium included arithmetic, geometry, astronomy and the theory of music.

At the same time, already in the 13th century, the system of teaching the seven liberal arts was considered obsolete. Subsequently, the liberal arts began to be regarded as independent sciences, essentially turning into the humanities. Nowadays to the liberal arts, it is customary included art, humanities (architecture, design, applied and visual arts, music, cinema and television, theatre, history, linguistics, literature, religious studies) and social sciences (sociology, cultural studies, political science, psychology) and some sciences, for example, mathematics.

At all times, art has acted as a catalyst for explicit and hidden socio-political processes in society. The aesthetic criteria of art and works of art gradually changed, and in the end, it led to a rethinking of the very role of art as a means of aesthetic and cultural education of society, since household items, disgusting things, and other objects began to be classified as art categories from the second half of the 20th century. There was even a widely used term "aesthetics disgust." It is definitely seen when comparing paintings of Renaissance or Classicism with works by Pablo Picasso, Edvard Munch and Salvador Dalí; or comparing the temples of Byzantium and the Gothic cathedrals of France with the buildings of Hundertwasser, Bofill Leví or Núnez Yanowsky, where dynamic, markedly deformed, expressive and hypertrophied images and buildings with intended mockery on well-established architectures canons had taken the place of the harmonious artworks or proportional architectural buildings with adjusted mathematical correlations and a distinct compositional structure.

The content of the terms "art" and "a work of art" has been an object of scholarly interest not only in previous centuries, but also since the first decades of the twentieth century, and these theories seem more relevant for the understanding of art in modern society. If you rely on the opinion of the theorist of art A. Gabrychevskyi of the 1920s, who distinguished a work of art as a perfect synthesis of mental and physical, spiritual and material, temporal and spatial, 
individual and supra-personal, random and necessary, resulting in the birth of another, not spatial and non-temporal, and considered the element of repeatability in spatial forms of art from the point of view of consolidation of mental effect 5 .

Art theorist Morris Weitz raised the issue of the impossibility to determine objectively the category "a work of art", because being a work of art is not a necessary condition for the existence of a work of art, therefore, attempts to clearly determine the concept of the term "art" is unpromising, resulting in an anti-essentialist theory of art on the basis of a conscious rejection of attempts to shape terminological definitions of artistic categories and the perception of the nature of art according to Ludwig Wittgenstein's "theory of affinities". ${ }^{6}$

The counterbalance to the anti-essentialist theory of art was the institutional theory of art proposed by George Dickie in the late 1970s, which proclaimed the direct dependence of a concrete and reasoned answer to the question of the nature of art on the rejection of the objective and functional features of works of art. This theory based on the fact that since the mid-twentieth century there have been dramatic changes in the signs of art by aesthetic properties and then art became closer to other spheres of human activity, which prompted the institution of art to give the artefacts the status of a work of art using the model rank or social status and recognizing only two criteria for the recognition of works of art.

V. Sheshtakov, V. Kemerov and O. Kukrak laid out their theoretical views on the content and purpose of art. According to them, art is a specific type of human activity aimed at creating carriers of aesthetic, cognitive and communication functions. $^{7}$

Today, the traditional classification of kinds of art involves their division into spatial or sculpturesque, temporal or dynamic and spatial-temporal types of art or fundamental (spatial and temporal and synthetic. In some theories, art is generally viewed as a cluster.

In the abridged dictionary under the general editorship of A. Marder, architecture and art are considered as "interrelated forms of aesthetic development of reality" and emphasizes their associations due to the presence of artificial forms and the result of purposeful creative human activity. Despite architecture and art have consolidating common features, the above-mentioned differences are in their final objective: works of art are aimed at the creation of

\section{N. Prokofiev, About art and art history. M., 1985. p. 161.}

6 M. Weitz, The Role of Theory in Aesthetics. Journal of Aesthetics and Art Criticism. Vol. 15, 1956, pp. 27-35.

7 V. P. Shestakov, V. E. Kemerov, O. N. Kukrak, Art. The centre of humanistic technology. 2019 Access method https://gtmarket.ru/concepts/7065 
the aesthetic values, while architecture is aimed at the making of the material and practical values of utilitarian purpose; the aesthetic values in architecture is the by-product and addition to its functional goal. "Traditionally, architecture often refers to art as a form of spatial applied art. However, being next to art as a form of aesthetic development of the world, architecture, entirely, as a phenomenon and a social institution does not belong to art, as it is a form of social being, a form of practical, and spiritual development of reality, and works of architecture (buildings, structures, their complexes) - not a reflection of the real world, but the world itself in all its materiality." 8

In this fact A. Marder saw the opposition of architecture to art, but emphasized that as a result of the commonality of the laws of aesthetic development of the world and the cooperation of architects and artists in creating the artificial environment for people's life, a synthesis of arts in architecture was developed, "which occurs during the physical and artistic-imaginative interaction of works of architecture and one or several works of monumental art." We should study in details the A. Marder's term "artistic architecture", which he considered as an art form and thought that the carrier of the artistic image in artistic architecture is architectural forms that obtain the meaning of an art form; and the principal point is not the utilitarian purpose of the building, but its artistic image. "Only architectural forms that are separate in space and completed within the framework of this separation creations can be a product of artistic architecture, are perceived by a person simultaneously as a single whole." 10 The term "artistic architecture" by its definition can be entered only at the object level. The relationship between artistic architecture and art itself, he sees in the fact that both are a specific form of social consciousness and are aimed at creation of an aesthetic image.

Theoretical artistic concepts are discussed in detail and analysed in the scientific publications of M. Dyomin and O. Ivashko. These works are devoted to the role of art and forms of artistic expression in modern society. In particular, they emphasized, that culture and art organize and develop a person, and civilization improves society, therefore, culture and civilization are not identical concepts. ${ }^{11}$

M. Dyomin noted that we can discuss the development and improvement of civilizations, but one cannot raise the issue of the development and improvement of art, which is aimed at the consciousness of each person, and at

8 A. P. Marder, Yu. M. Yevreinov, O. M. Plamenytska et al. Architecture. Abridged dictionary. Under the general editorship of A. P. Marder. Kyiv, 1995. p. 110.

9 Ibid, p. 28.

10 Ibid p. 29.

11 M. M. Dyomin, M. I. Orlenko, The systematic approach..., op. cit., O. Iwaszko, op. cit. 
society as a whole. And the greater the percentage of people, the more civilized society is. So, culture and art directly develop the consciousness of society. The attitude of society to individual phenomena, as well as specific works of art, may change under the influence of particular circumstances of political and aesthetic order. The thing that was considered a work of art before may not be considered a work of art at all now or in the future, if a change in aesthetic criteria has occurred in society. On the other hand, an introduction to the categories of the art of phenomena that were not previously related to them also indicates the presence of changes in society, and it is possible to analyse what these changes were caused by (most often these are socio-political factors).

It is impossible to report that culture and art developed during the existence of mankind, since art is a part of culture and it is unreasonable to compare artworks of various periods and styles with each other, to consider which is the best and worst work of art - cave images of the Neolithic era, an ancient Egyptian or ancient Greek sculpture, painting of the Renaissance or Baroque, a Persian miniature or Chinese traditional painting. In their publications and reports at conferences, it was noted that the style and the manner of performance could not be a criterion in the estimation of works of art; there is only one category - perfection or level of mastery, transferring the work of art into the category of culture. The perfection of a work of art can be objectively assessed only after some time, time is needed since contemporaries are often unable to do this (as was the case with works by Bach, Modigliani and other artists). The assessment of a work of art is not an objective, unchanging criterion since it is an indicator of the attitude of society to a particular work and the canons of aesthetics, but it is experts who create this assessment; the experts assess a work of art according to their criteria, and customers and viewers, not experts, have their assessment patterns. Each level of assessment is determined by the specific character of knowledge and an objective understanding of a particular artistic phenomenon. Together, this leads to the universal acceptance of a particular artistic phenomenon as a work of art.

M. Dyomin and O. Ivashko stated that there is no single criterion of a work of art, motivating it with the changing tastes of society, but they emphasized that the assessment of a particular artwork as a synonym for perfection and artistic mastery can remain consistent during a change of generations as a result of the supremacy of proportions, narrative, colours. ${ }^{12}$ The excellence of performance is the only criterion that allows you to compare different kinds of art of different periods and styles. 
Based on this, it can be noted that the creation of a masterpiece of art cannot be the goal of the artist since the category of masterpiece is given by time.

\section{The specificity of meaningful content of the terms "art" and "a work of art" in the restoration industry}

The issue of the restoration of works of art is a problem of contemporary art worldwide, since, according to specialists, only $1 / 8-1 / 10$ works of the Renaissance have come to our days, and a significant part of them being in the damaged or fragmentary state. So, the restoration applies to all types of art, not limited to architecture. The preservation of monuments of art and architecture is enshrined in international charters and declarations, where they are proclaimed a significant part of the cultural heritage of mankind (Venice Charter for the Preservation and Restoration of Monuments and Sites (1964), International Charter on the Legacy of Traditional Construction (1999), International Charter on Principles of Analysis, preservation and restoration of architectural heritage buildings (2003), etc.). Some documents deal specifically with the principles of preserving works of art - for example, the Principles of Insurance and the Conservation / Restoration of Wall Images, adopted by the 14th General Assembly of ICOMOS in 2003, proclaiming that "wall images are a cultural manifestation of human creativity in the course of history, leaks, from rock art to contemporary works of wall art. Their damage or destruction, accidental or deliberate, is a loss that concerns a significant part of the cultural heritage of humanity"13. "According to the Venice Charter, the preservation/restoration of wall images should be accompanied by a well-defined documentation program in the form of an analytical and critical report, including illustrations ..."14

The restoration industry is, on the one hand, a science that synthesizes the achievements of numerous sciences to obtain a certain result, on the other hand - the most conservative branch of art and architecture since it bases on the preservation of the authenticity of the work. Taking into account the goals and objectives of the restoration activities, it is necessary to consider the building as a separate integrity regardless of its function, from the perspective of determining the main objects (elements) of the restoration intervention, taking into account their importance in the building's activities (supporting, enclosing structures, exterior, artistic etc.). Since in the restoration the category "a work of art" determines works of art of a different time, different types of art and various art techniques, there are difficulties in developing approaches to the

13 International principles of the protection of immovable cultural heritage. Kyiv, 2008. p. 114.

14 Ibid, p. 115. 
preservation of these works. A significant feature in the restoration industry is the preservation of paintings, frescoes, sculptures, carvings, fabrics, etc. Thus, the restoration industry is also a synthesis of the arts, as it covers not only the restoration of the architecturally-constructive structural element but also works of art.

The object of restoration is firstly a work of art or architecture, and only then a landmark. The status of a monument of architecture, like other objects of the immovable heritage, provides for the restoration or conservation of the monument as a whole or its components or elements, which are subjects of preservation.

An object of restoration is categorised into the architectural and constructive system, exterior, interior, equipment and monumental-decorative art (the category of works of art can be applied to everything, except the architectural and constructive system, concerning components and details - wall paintings, paintings, sculpture, etc.) To systematize the approaches to preserving the authentic form of works of art, a systematic approach is used, which allows us to imagine the presence of works of art-decor elements on various parts of the exterior surfaces of restoration objects and in interiors.

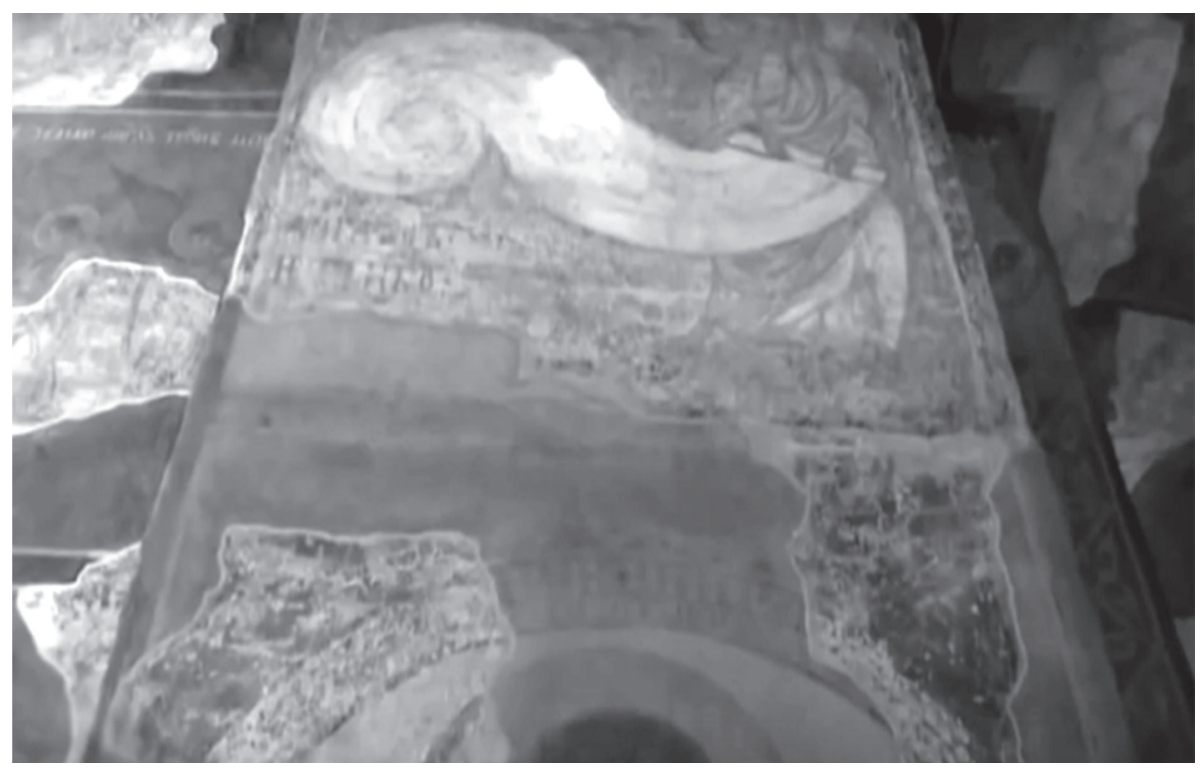

Fig.1. The Kyrylivska church (St. Cyril's Church), Kyiv. The monument of architecture and monumental mural painting (12th century) of the universal significance. The Angel rolling the heaven in a scroll. The Last Judgment. A fresco of the 12th century. The east pylon of the south pillar of the narthex. Photo of "Ukrrestavratsiya" corporation, 2019. 
By the same principle, it is possible to systematise the location of those works of art that perform purely decorative functions, in particular works of monumental-decorative art, including painting, mosaic, relief, sculpture, stained glass, artistic metal. In this series, all stucco details, reliefs, a column, an arch (if they perform purely decorative functions), mosaic compositions on ceilings and walls, mosaic floors, painting on internal and external surfaces are analysed. Each element is restored by the developed restoration techniques.

Decor elements can be represented by their location on the outer surfaces of the building, works of monumental and decorative art by the locating on the inner and outer surfaces. So, in the first case, the locations of the decor-works of art on the facades are emphasized, in the second case, the emphasis is placed on the types of monumental-decorative art (painting, mosaic, relief, sculpture, stained glass, artistic metal) - carriers of decorative functions.

The need to systematize the decor elements - works of art is due, firstly, to their diversity in materials, manufacturing techniques, and then restoration methods. Today, national restorers have to solve much more complicated issues than their predecessors, and some methods of reconditioning and restoring decorative elements are unique, which will be discussed in the following sections (for example, methods of restoration of paintings of Kyrylivska church, methods of restoration of mosaics of the Old Russian period in the St. Michael's Golden-Domed Monastery, the iconostasis of the St. Michael's Golden-domed Cathedral and the Assumption Cathedral of Kyiv-Pechersk Lavra, stone decor of the St. Volodymyr's Cathedral in Chersonese) (fig. 1, 2).

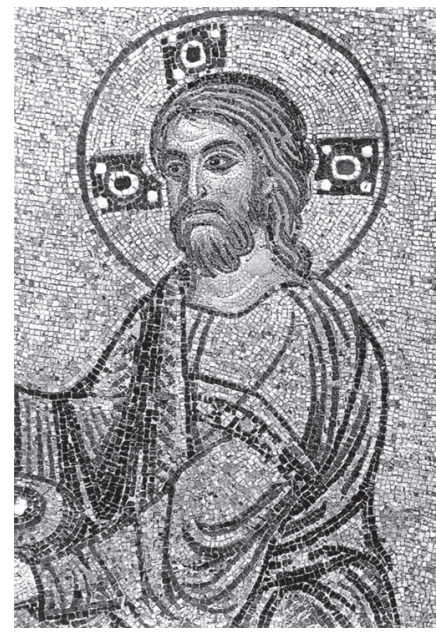

Fig. 2. The Saint Michael's Golden-Domed Cathedral, Kyiv. The Eucharist. Christ. Details of the mosaic in the altar apse of the 12th century. Photo of "Ukrrestavratsiya" corporation, 2015. 
The interiors of a definite period were identified by the use of particular materials and techniques, therefore the difficulties and the causes of the emergency condition and the restoration techniques have their hallmarks (in the interiors of the 9th-12th centuries - mosaics and frescoes, in the 13th-15th centuries - murals in the fresco technique - secco, secco on lime plaster, in the 17th-19th centuries - oil painting). (fig. 1) In the restoration, the only criterion that allows an artefact to be considered a work of art is the degree of mastery in the period of creation of the artefact and in comparison with several similar works of art. At the same time, the sculpture of Pinzel, the mural of the folk master in the old wooden church, and the painting of rural houses, if it is authentic, of specified period of limitations, and is distinguished by originality or mastery in the execution of a series of similar murals, are considered as a work of art. Another peculiarity of the approach to art in restoration is the constancy of its aesthetic estimation: what was considered a work of art in restoration is unchanged, despite variations in the criteria for aesthetic assessment in society, and in restoration, the criteria for assessing a work of art are slightly different than of the art outside the restoration industry. Even in the case when the works of art in the restoration are not the representatives of the author's style, they are evidence of architectural features (facade and interior elements) and the art of their time, turning them into objects of protection, up to preserving the authentic techniques of performance during restoration activities.

The main features of the interiors of the Old Russian period are associated with the presence of mosaics and frescoes, carved slate slabs, marble columns and mosaic floors (Saint Sophia Cathedral, Church of the Savior on Berestove It requires understanding of mosaic and fresco techniques, and the restoration work is preceded by thorough archival and site researches, especially since each temple is distinguished by its particular colour gamut and mosaic colour set. Ancient Russian temples of the 11th-12th centuries decorated with mosaics, which were located at the zenith of the dome, on sails, in the central apse on the walls. It was a long-standing view of monumental and decorative art.

The mosaic constructive scheme is as follows: the limestone-sand layer of plaster with the addition of powdered bricks were laid on a brick base, a mosaic set of multi-coloured smalt in the form of cubes, which had a coloured background. Mosaic soil with a set is marked with strength and has a thickness of 5-6 cm, in the case of detachment from an array of masonry arch several centimetres with the formation of cavities, it can maintain the integrity of the set only due to sphericity, adhesion strength and steel dowel pins, clogged during the previous restoration measures.

The main problems of the existence of mosaics of smalt, golden smalt and natural stone are associated with delamination through constant moistening of the plaster from the base (lime base), stratification of layers from each other, 
the bio damage of moistened plaster. So, the main problems are characteristic of lime plaster. It leads to a breakdown of the basement under the mosaic and mosaic set fixing, changes in the structure of smalt, scuffing, detachment and loss of gilding laid on the surface of the mosaic, dimming of gilding as a result of oxidation of bronze paint, which at one time tinted the loss of gilding and pollution. The process of restoration of mosaics and mosaic floors is described in the scholarly section of the manual by A. Ostapchuk. ${ }^{15}$ The difficulties of the emergency state of mosaics and the ways to cope with them are analysed on the basis of the case of the mosaics of St. Sophia's Cathedral.

The interiors of the churches of the Old Russian period were decorated with mosaic floors, the remains of such floor can be seen in the St. Sophia Cathedral. Traditions of such floors appeared in antiquity, the typical size of stones for a mosaic set was $0.5 \times 0.3 \mathrm{~cm}$. The principal difficulty of such floors is the appearance of dints, upheaval and swelling of a mosaic set.

In the scientific section, I. P. Dorofiienko and A. Y. Marampolskyi described the specific features of the restoration of the fresco murals. ${ }^{16}$ The main problems of fresco murals are associated with the wetting of the walls, with the presence of cracks in the masonry within the frescoes, cracking and delamination of lime in the composition of plaster, delamination of plaster due to moistening, destruction and loss of paint layer, the presence of later oil layers.

It should be mentioned that one of the principal parts of the restoration documentation is the cartogram of the state of painting, where, as a rule, painting on the developed surfaces is taken into account. ${ }^{17}$ The photogrammetric method of manufacturing architectural scans is also applied [3, p. 550]. The cartograms of the condition of painting became the basis for calculating the volumes and types of restoration measures and the evaluation act on the estimate; it is the basis for cartograms of probing, cartograms of project proposals for the restoration of wall paintings, cartograms of the restoration work. ${ }^{18}$

The temples of the ancient Russian period underwent large-scale reconstructions in the 17th-18th centuries. (the St. Sophia Cathedral, the St. Michael's Golden-Domed Cathedral, the Assumption Cathedral of the Kyiv-Pechersk Lavra) (fig. 3), therefore, the interiors combine Old Russian traditions and traditions of the 17th-18th centuries and even the later synodal period of the 19th century (fig. 4). Since the restoration concept of "a work of art" is adapted to works of different periods, and all of them are considered equally valuable and

15 Conservation and restoration of architectural monuments. Guidance manual. Edited by M. I. Orlenko Kyiv-Lviv, 1996. p. 548.

16 Ibid.

17 Ibid. p. 550

18 Ibid. 


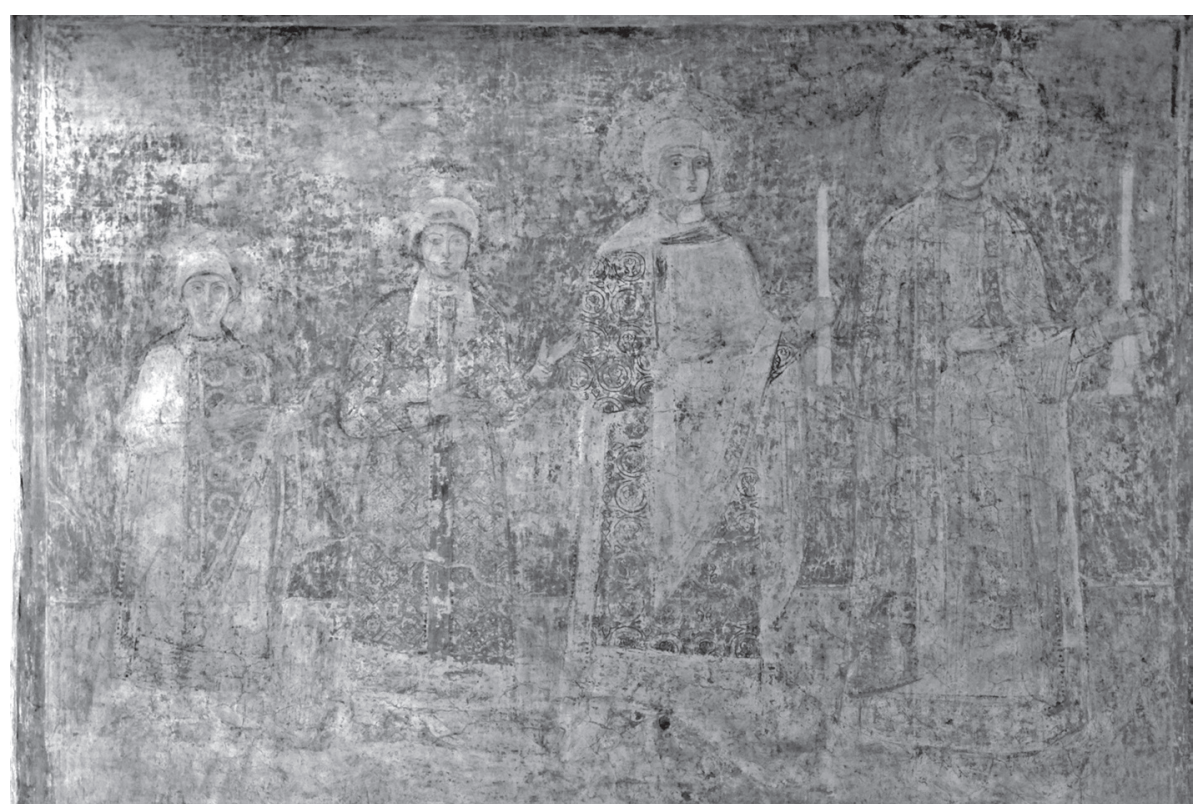

Fig.3. The Saint Sophia's Cathedral in Kyiv, an outstanding monument of architecture and monumental painting (11th - 18th centuries). The Yaroslav's family. A frescoe of the 11th century. The central nave. Photo of "Ukrrestavratsiya" corporation, 2008.

in need of preservation, later pictorial layers are removed by transferring them to a new duralumin base and thus also retain with the possibility of exposure. ${ }^{19}$

Magnificence, bright colours of the wallpaper, luxurious upholstery and drapery material of walls and furniture, gilded stucco decor of the Baroque epoch, were inherent to interiors of the 17th-18th centuries. At the same time, the interiors of this period with time were subjected to later layers, clearly visible on the example of the Mariinskyi Palace. ${ }^{20}$ The colour decision of the buildings of this time was distinguished by the integrity and completeness of the plan. It fully corresponded to the function of a representative structure for official receptions.

19 Ibid. p. 561.

20 The Mariinskyi Palace. The technology of painting an experimental plot of plaster on the facades. Conclusion on the results of the technological survey. Recommendations on the technology of repair and restoration work on the facades. Conclusion on the results of a technological survey of brickwork of the Mariinskyi Palace in Kyiv. The draft project of reconstruction and restoration. Photo fixation album. Kyiv, 1987, 1989, 1997, 2002. 158 p. 


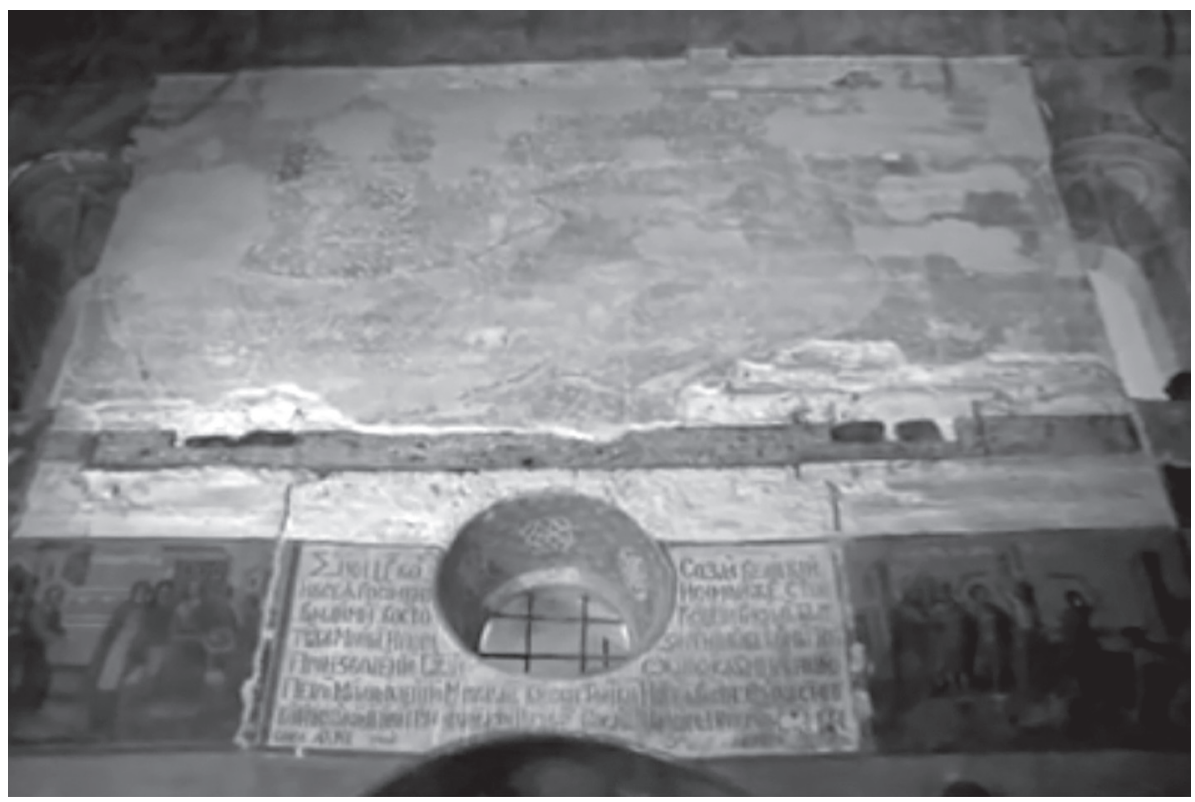

Fig.4. The Church of the Saviour at Berestovo, an architectural monument (11th-12th centuries), Kyiv. 'Miraculous Fishing'. ("Christ's Appearance to the disciples on the Sea of Tiberias"). The frescoe of the 11th century. Photo of "Ukrrestavratsiya" corporation, 2019.

The evolution of interior changes often proceeded in parallel with the facade changes, however, the facade kept its stylistic colouring for a long time, while the interiors experienced significant changes, each new building owner made individual adjustments.

The palace interiors of the 17th century (the so-called "Peter's style") had the following features: the White (Throne) great hall with luxurious stucco moulding of ceiling and walls, a grand chandelier, the bottom of the walls of the ceremonial rooms were trimmed with low wooden carved panels, above them the walls of the staterooms were covered with fabrics or canvas pasted over multi-coloured "flock" wallpaper in gilded white carved frames and decorated with large mirrors and drapes, part of the walls are plastered, whitewashed, painted. ${ }^{21}$ Other staterooms are grouped around the Throne room, and the main ones are colour-accented.

21 Ibid. p. 82. 
The representative interiors of the end of the 18th - early 19th century obtained the following details: ceiling paintings, wallpaper from canvas, pompadour velvet with gold edging to match the furniture of the throne hall, durable silk and half-silk for wall covering, artificial marble cladding [5, p. 83], marbled paper wallpaper is used for upholstering walls, or colouring with patterns and borders. The hallmark of that time was the use of the fabric of the same colour and texture for walls, furniture and curtains in the same room. The central royal throne becomes the main accent of the throne room. During that period of the palace's existence, the main colour scale of the staterooms was blue; the walls were upholstered with flaming fabric.

Representative interiors of the 19th century had the following features: instead of marble, cement was used in the decoration of the walls, a few gildings was only on the eaves and in some places on the ceilings. After reconstruction, instead of wallpaper, a gentle yellow-brown colouring was used; the interiors became much more modest, the walls of individual ceremonial rooms were of grey-lilac and blue-white colours, as well as carpet and furniture. ${ }^{22}$

In the interiors of the 17th - early 20th centuries on the walls and ceilings of buildings, stucco décor was used, sometimes gilded, from the beginning of the 20th century they used cement decor.

A special feature of the 19th-century interiors is the transition from the strict traditions of classicism of the first half of the 19th century to the agility of the second half of the 19th century. A mixture of styles can be seen in the decoration of the auditorium of Odessa Opera Theatre, where the stylistics of Viennese Baroque, Italian Renaissance and French Rococo are combined. Thus, the peculiarities of the interiors of this period consist of excessive magnificence, the use of sculpture, bas-reliefs, picturesque panels, gilding, openwork metal elements and lighting elements. Restoration technologies include the restoration of sculptures, reliefs, ornaments with gilding, oil and tempera wall painting, artistic metal constructions (fig. 5).

Interiors of the second half of the 19th century are divided into mass (in residential buildings, typical public buildings) and unique (in the most significant public buildings, palaces). In mass interiors, moulded parts of eaves and decorated ceilings were typical, of mass production. In the unique interiors, each element was designed by celebrated architects, artists, sculptors, and carvers, therefore it is of great artistic and architectural value.

Unique interiors of the second half of the 19th century are preserved in Odessa Opera Theatre, where there are various types of monumental and decorative art, typical for buildings of that period (painting, relief - bas-reliefs, sculpture, stucco decoration, artistic metal, the lighting devices - the main

22 Ibid. p. 67. 


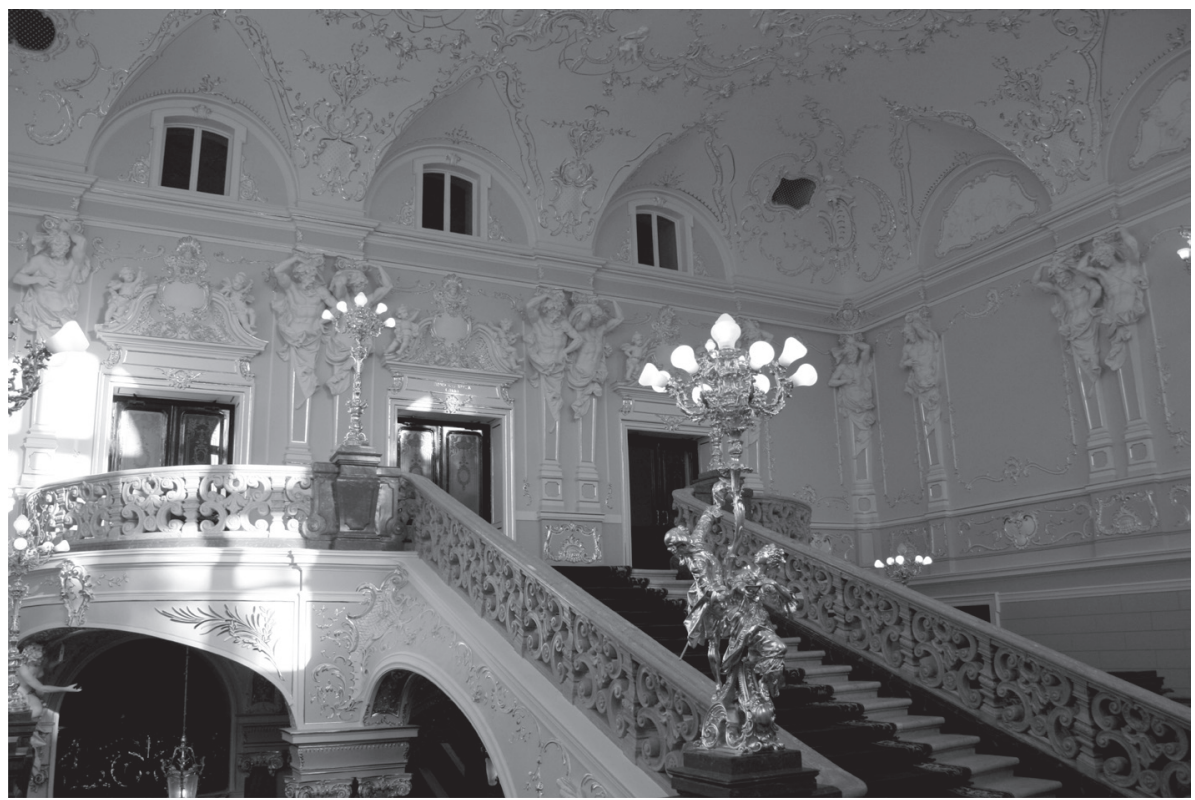

Fig.5. Odessa National Academic Opera and Ballet Theatre. The white stairs. Photo of "Ukrrestavratsiya" corporation, 2007.

chandelier, lamps, candelabrum, by authors' designs) ${ }^{23}$ (fig. 5). Characteristic of this period is the decoration of walls, ceilings, columns, stairs, tiers, lobbies, aisles to the lies of spectacular buildings with sculptures of cupids, putti, Atlantes, muses, satyrs, stucco ornaments with gilding. According to the author's sketch of the artist A. Golovin, a theatre curtain was created. The most luxurious room of the best opera houses is the auditorium, where the ceiling can be decorated with tempera or oil painting (the ceiling of Odessa Opera Theatre is decorated with four paintings of the artist F. Leffler with the scenes from Shakespeare's plays, and in the centre of the ceiling there is a unique large chandelier). In the decoration of staircases, it was used mosaic floors with a pattern, stair railing made of multicolour artificial marble.

However, a mixture of styles, the synthesis of varieties of monumental and decorative art due to the mastery of architects is perceived harmoniously and makes an aesthetic impression.

23 The monument of architecture of the XIX century Odessa National Academic Theatre of Opera and Ballet. Restoration project II stage. Working project. Project proposals for the restoration of interiors. East portico. Complex program for the preservation of Odessa National Academic Theatre of Opera and Ballet. Kyiv, 1995-1998. 200 p. 
The principal problems of the emergency state of the monumental-decorative decoration of unique spectacular buildings of the second half of the 19th century may be associated with the following:

- with the destructive impact of the emergency condition of the supporting structures on the state of the stucco decor and interiors; ${ }^{24}$

- from wetting the decorated ceiling, walls and decor, contamination of the paint layer, peeling off the plaster from the base, chips of the decoration of the ceiling and corrosion of metal elements, with changes in the relief of the decorated ceiling as a result of repairs;

- with the detachment of the paint layer of the painting of the ceiling due to damage to the coating;

- with the deformation of the stairs, mosaic and parquet floors, the presence of cracks, chips and with a change in the original figure..$^{25}$

- with a change in the original lighting and loss of decorative elements.

The interiors of the early twentieth century were notable for the spread of modernist styling in modelling, metal and ceramic elements, oil paintings and tempera walls, stained glass windows, therefore restoration technologies are aimed at restoring stucco and beautiful decor, stained glass windows, metal elements made according to the author's designs of heating appliances and floors. As the interiors of the second half of the 19th century, the interiors of the beginning of the 20th century were massive, with typical factory-made decor, and the unique one (fig. 6).

Thus, in the objects of restoration, it is reasonable to discuss the art synthesis, when a specific combination of different types of art, works for a common result - the creation of an image of a particular epoch with the maximum observation of the principles of authenticity.

\section{Conclusions}

An analysis of the meaningful content of the terms "art" and "work of art" in society, in theories of art and the restoration industry, proves that the main criterion for assigning an artefact to the category of art is the mastery of its manufacture. Most often, the referring of creation to art masterpieces does not occur by contemporaries, but by descendants, since for this the work must pass the test of time. Since art is a category of culture that is directed at the evolution of people and the development of social consciousness, and the quantity of such developed personalities forms the level of civilization of society,

24 Ibid. p. 36.

25 Ibid. p. 39. 


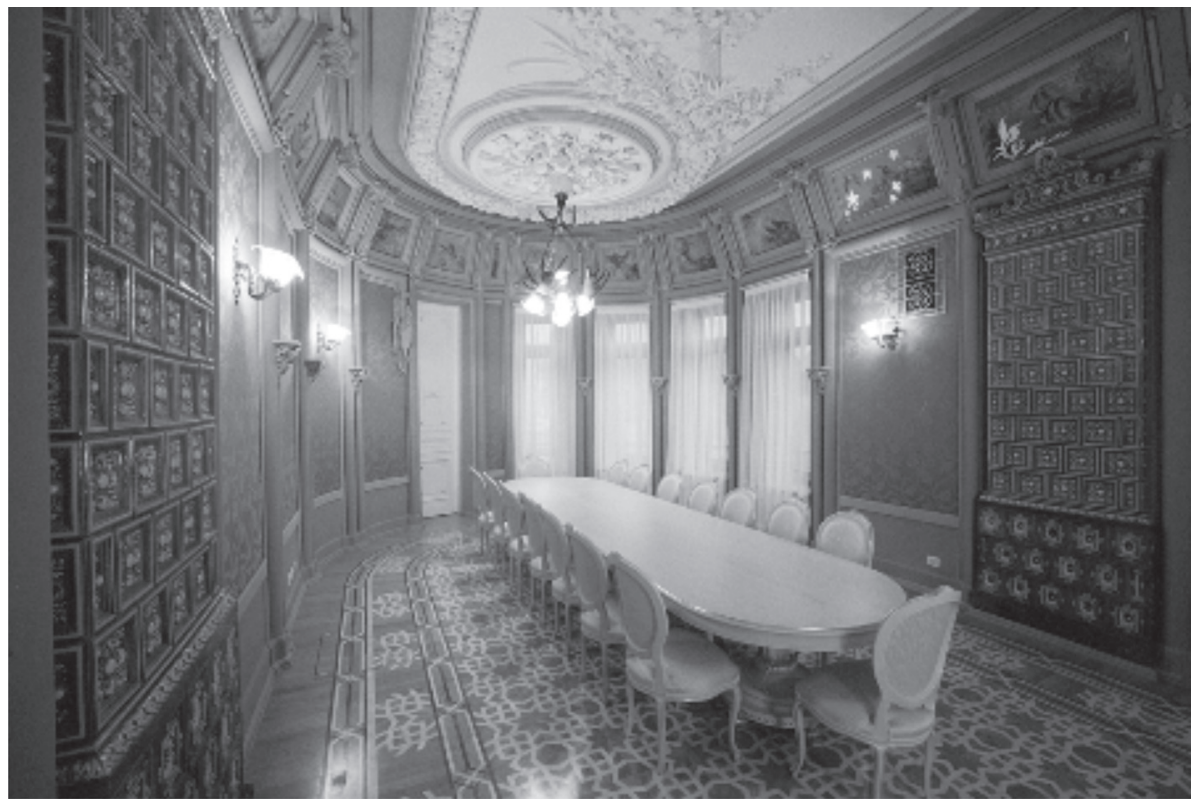

Fig.6. The house of architect Władysław Horodecki. The House with Chimaeras (1901-1902) Kyiv. Restored in 2001-2003.The current interior views after restoration. Photo of "Ukrrestavratsiya" corporation, 2003.

even despite fundamental changes in attitudes towards art in contemporary society and rethinking the educational aesthetic function of art, the category of art is necessary for society. If we discuss the meaningful content of the term "art" and "work of art" in the restoration, the category "work of art" includes works and objects of a particular period of limitations, which differ in the level of perfection or represent their epoch, but in all cases are carriers of aesthetic positive properties (the restoration is strange to "aesthetics disgust", such as the modern museum of toilets or the exposure of the cut hog carcass in one of the museums in London).

\section{BIBLIOGRAPHY:}

Dyomin, M. M., Orlenko, M. I., The systematic approach to monuments and restoration activities. Urban planning and territorial planning: Scientific and technical collection. Osietrin, M. M. (Ed.) Kyiv, KNUCA. Issue 65, 2017, pp. 21-32.

Iwaszko, O. Społeczna Przyroda Nowych Artystycznych kierunków w Miejskim Środowisku. Przestrzeń / Urbanistyka / Architektura, 2/2018, pp. 167-176. 
Conservation and restoration of architectural monuments. Guidance manual. Edited by M. I. Orlenko Kyiv-Lviv, 1996.

Marder, A. P., Yevreinov, Yu. M., Plamenytska, O. A. et al. Architecture. Abridged dictionary. Under the general editorship of A. P. Marder. Kyiv, 1995.

The Mariinskyi Palace. The technology of painting an experimental plot of plaster on the facades. Conclusion on the results of the technological survey. Recommendations on the technology of repair and restoration work on the facades. Conclusion on the results of a technological survey of brickwork of the Mariinskyi Palace in Kyiv. The draft project of reconstruction and restoration. Photo fixation album. Kyiv, 1987, 1989, 1997, 2002.

Art - a short dictionary on aesthetics. http://esthetics.ru - iskusstvo. July 29, 2013.

International principles of the protection of immovable cultural heritage. Kyiv, 2008.

The monument of architecture of the XIX century Odessa National Academic Theatre of Opera and Ballet. Restoration project II stage. Working project. Project proposals for the restoration of interiors. East portico. Complex program for the preservation of Odessa National Academic Theatre of Opera and Ballet. Kyiv, 1995-1998.

Prokofiev, V. N. About art and art history. M., 1985.

Shestakov, V. P., Kemerov, V. E., \& Kukrak, O. N. Art. The centre of humanistic technology. 2019 Access method https://gtmarket.ru/concepts/7065

Weitz, Morris. The Role of Theory in Aesthetics. Journal of Aesthetics and Art Criticism. Vol. 15, 1956. pp. 27-35.

\section{POJĘCIE SZTUKI I DZIAŁA SZTUKI W TEORII SZTUKI I KONSERWACJI (streszczenie)}

Jawne i ukryte procesy społeczno-polityczne we wszystkich epokach dziejowych miały bezpośredni wpływ na działalność artystyczną. Poczynając od pierwszej dekady XX wieku stopniowej transformacji ulega znaczenie terminu «sztuka» oraz «dzieło sztuki». Od tego momentu sztuka nie zawsze jest postrzegana w związku z kategorią piękna. Zaszły także zmiany związane z doborem artefaktów artystycznych. Proces tworzenia odbywa się stopniowo, poprzez transformację zaobserwowanego zjawiska lub bodźca, a następnie ulega żywiołowej zmianie przy pomocy odpowiednich środków i twórców. Później staje często zjawiskiem społecznym i zajmuje pewną niszę w życiu kulturalnym społeczeństwa. Sztuka zatem jest także środkiem edukacji społeczeństwa, rozwijającym się zgodnie z zasadami estetyki.

Przemysł związany z restauracją dzieł sztuki jest dość konserwatywny. Przestrzega kryteriów definiowania dzieła sztuki, jego zachowania i reprodukcji. Rozwinął się w XX i XXI wieku, a renowacja obejmuje dziś nie tylko malarstwo, malowidła ścienne, rzeźbę, a również meble, tkaniny itp.

Słowa kluczowe: sztuka, dzieło sztuki, restauracja, kryteria określenia 
Mykola Orlenko - Doctor of Architecture (2018), Professor (2017), Laureate of the State Prize of Ukraine in the field of architecture in 2004 (Presidential Decree No. 673/2004 of June 23, 2004), Merited Builder of Ukraine (1997), since 1982 - President of the Corporation, since 2012 - Honorary President of the "Ukrrestavratsiya" corporation, Academician of the Academy of Construction of Ukraine. He was directly involved in the restoration of more than 800 monuments of Ukraine, the author of 10 monographs and about 100 scientific articles. Scientific interests and directions of scientific activity: restoration of architectural monuments and works of art.

1. Orlenko M., Ivashko Yu. Lighting devices in the Secession as the component of "Gesamtkunstwerk" and the issues of restoration Smart Project, Building and City/ Środowisko Mieszkaniowe (Housing environment). Kraków, 19/2017. pp.150-156.

2. Orlenko M., IvashkoYu. The specifics of lighting of restoration objects (on the example of stave and stone church structures) "Światło w Architekturze Środowisko Mieszkaniowe (Housing environment)”, Kraków, 20/2017. pp.130-136.

3. Orlenko M. Restoration and conservation work technologies for sculptures. European Journal of Technical and Natural Sciences, Vienna, no. 6 / 2017. pp. 7-11. DOI: http:// yadi.sk/d/FHU8gdOw3Qwxuj .

4. Orlenko M. I. Unique techniques of rebuilding the Old Russian mosaics / Contemporary problems of architecture and urban construction: Scientific-Technical collection. Editor-in-chief M. M. Dyomin. Kyiv National University of Construction and Architecture, 2017. Edition 47. pp. 138-148.

5. Orlenko M. St. Michael's Golden-Domed Monastery: methodological principles and chronology of rebuilding. Kyiv, 2002.

6. Orlenko M. Saint Volodymyr Cathedral in Chersonesos: methodological principles and chronology of rebuilding. Kyiv,2015.

7. Orlenko M. Uspensky Cathedral of Kyiv Pechersk Lavra: methodological principles and chronology of rebuilding. Kyiv, 2015.

Yulia Ivashko - PhD of Architecture (2013), Professor (2014), Doctor habilitatus, nostrificated (2018). She is the author of over 550 scientific publications and monographs. Scientific interests and directions of scientific activity: folk architecture of different countries of the world, architecture and art of historicism - eclecticism and Art Nouveau, Islamic architecture and art, architecture and art of China, restoration of works of art.

1. Ivashko Yu. Houses of Kyiv with gothic elements (stydy of history and architecture) (Editor-in-chief M. Dyomin). Kyiv, 2004.

2. Ivashko Yu. Art Nouveau style in architecture of Kyiv (Editor-in-chief M. Dyomin). Kyiv, 2007.

3. Ivashko Yu., Li Shuang. Art Nouveau style of Western Europe, Ukraine and China: the ways of transformation and implementation (Editor-in-chief M. Dyomin). Kyiv, 2015. 
4. Orlenko M., Ivashko Yu., Li Shuang. Reincarnation of the Northern National Romanticism: investigation and experience in the restoration of objects (Editor-in-chief M. Dyomin). Kyiv, 2016.

5. Dyomin M., Ivashko Yu., Rezga K. Mosques of Algeria: Architectural and Urban Aspects. Kyiv, 2019. 